НАУКОВИЙ ВІСНИК

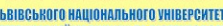
імені С.3. гжищьког Scientific messenger of Liviv National Univer:
Veterinary Medicine and Biotechnologie

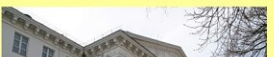

An 11 i II II It 1. 2019
Науковий вісник Аьвівського національного університету ветеринарної медицини та біотехнологій імені С.3. Гжицького. Серія: Економічні науки

\author{
Scientific Messenger of Lviv National University \\ of Veterinary Medicine and Biotechnologies. \\ Series: Economical Sciences
}

\title{
Features of functioning of the marketing system of rural territories of the border region at the present stage of European integration of Ukraine
}

\author{
I. Kravtsiv, S. Tkach, I. Urban \\ Stepan Gzhytskyi National University of Veterinary Medicine and Biotechnologies Lviv, Ukraine
}

Article info

Received 05.09.2019

Received in revised form 07.10 .2019

Accepted 08.10.2019

Stepan Gzhytskyi National University of Veterinary Medicine and Biotechnologies Lviv, Pekarska Str., 50, Lviv, 79010, Ukraine.

Tel.: +38-067-722-64-90 E-mail: KravtsivIryna@ukr.net
Kravtsiv, I., Tkach, S., \& Urban, I. (2019 Features of functioning of the marketing system of rural territories of the border region at the present stage of European integration of Ukraine. Scientific Messenger of Lviv National University of Veterinary Medicine and Biotechnologies. Series: Economical Sciences, 21(92), 27-30. doi: 10.32718/nvlvet-e9306

The article investigates the development of marketing of rural areas of the border region in which the main socio-economic and integration processes affecting the functioning of the rural economy are taking place. Priority attention is paid to actualization of marketing issues in the activities of local self-government bodies of rural communities of Ukraine in the context of the new challenges of European integration. The main components of the marketing system of the rural areas of the frontier region are outlined, which should be focused in the process of adaptation of the institutional environment of Ukraine to the institutional standards of the EU: social and economic potential of the rural territory, contractors (subjects of economic activity), markets (agrarian, financial, labor resources, etc.), intermediaries (public authorities and local self-government, educational institutions and scientific institutions, public organizations, etc.), competitors (rural areas of other regions gions, including neighboring border regions of the EU member states) and contact points (potential investors, media, political parties and movements, etc.). The specifics of the formation and development of the marketing system of the rural territories of the border region are investigated. In particular, based on the application of the cluster analysis method, four main types of rural areas in the Lviv Oblast (clusters) were identified, for each of them there is an own model of optimal development of the marketing system: a cluster of high investment attractiveness; satellite-transit cluster; agrarian cluster; conditional peripheral cluster. It was revealed that the main problems that restrict the development of marketing of rural areas in each of the four types of clusters mentioned above, as in the Lviv region, as well as in other border regions of the EU with the regions of Ukraine, are: low level of financial capacity of local self-government bodies of rural communities. The number is due to the small number of their population, small-scale agricultural production, which is carried out mainly in private peasant farms, as well as the presence of a number of socio-psychological problems caused by poverty of the rural population, its social apathy and pessimism. The key barriers to be addressed include: under-financing of the rural marketing sector as a whole and the lack of attention given to its development by the heads of local government bodies of rural communities; low quality of human and social capital of the village, generated by the outflow of skilled personnel in the city and abroad; the lack of modern marketing, transport and logistics and engineering infrastructure, which complicates the formation of a positive image of rural areas and the attraction of foreign capital and investment resources in their development; demotivation of business entities for the introduction of innovations and establishing mutually beneficial cooperation with territorial communities, which makes it impossible to effectively implement public-private partnership projects at the local level.

Key words: marketing, rural territories, European integration, local self-government, border region, economic development.

\section{Особливості функціонування системи маркетингу сільських територій прикордонного регіону на сучасному етапі європейської інтеграції України}

\author{
І.К. Кравців, С.М. Ткач, І.Р. Урбан
}


Львівський національний університет ветеринарної медицини та біотехнологій імені С.3. Гжицького, м. Львів. Україна

Досліджується розвиток маркетингу сільських територій прикордонного регіону в якому відбуваються основні соичіальноекономічні та інтеграційні прочеси, щу впливають на функціонування сільської економіки. Периочергову увагу приділено актуалізачії маркетингової проблематики в діяльності органів місцевого самоврядування сільських територіальних громад України в умовах нових викликів європейської інтеграції. Окреслено основні складові системи маркетингу сільських територій прикордонного регіону, на які має фокусуватися увага у процесі адаптації інституційного середовища Украӥни до інституційних стандартів ЄС а саме: сочіально-економічний потенціал сільської території, контрагенти (суб'єкти господарської діяльності), ринки (аграрний, фінансовий, трудових ресурсів тощу), посередники (органи державної влади та місцевого самоврядування, навчальні заклади та наукові установи, громадські організачії та ін.), конкуренти (сільські територї інших регіонів, включаючи сусідні прикордонні регіони країн-членів ЄС) та контактні аудиторії (потенційні інвестори, засоби масової інформації, політичні партії та рухи тощьо). Досліджено специифіку формування та розвиток системи маркетингу сільських територій прикордонного регіону. Зокрема, на основі застосування методу кластерного аналізу було виявлено чотири основні типи сільських територій Львівської області (кластери), для кожного з яких існує власна модель оптимального розвитку системи маркетингу: кластер високої інвестиційної привабливості; сателітно-транзитний кластер; аграрний кластер; умовно-периферійний кластер. Виявлено, щзо основними проблемами, які обмежують розвиток маркетингу сільських територій в кожному із чотирьох зазначених типів кластерів як у Львівській області, так і в інших прикордонних з СС регіонах України, є: низький рівень фінансової спроможності органів місиевого самоврядування сільських територіальних громад, у тому числі зумовлена малочисельністю їх населення, дрібнотоварність виробництва сільськогосподарської продукиіі, яке здійснюється переважно в особистих селянських господарствах, а також наявність низки суспільно-психологічних проблем, породжених бідністю сільського населення, його сочіальною апатією та песимізмом. Окреслено ключові бар'єри, серед яких: недофінансування сфери маркетингу сільських територій загалом та недостатня увагу, шо приділяється його розвитку керівниками органів місцевого самоврядування сільських територіальних громад; низька якість людського та соціального капіталу села, породжена відтоком кваліфікованих кадрів у міста $і$ за кордон; відсутність сучасної маркетингової, транспортно-логістичної та інженерної інфраструктури, щзо ускладнює формування позитивного іміджу сільських територій $і$ залучення іноземного капіталу та інвестиційних ресурсів у їх розвиток; демотивація господарюючих суб 'єктів до впровадження інновацій та налагодження взаємовигідного співробітництва з територіальними громадами, щзо унеможливлює ефективну реалізацію проектів державно-приватного партнерства на локальному рівні.

Ключові слова: маркетинг, сільські територї, європейська інтеграція, місиеве самоврядування, прикордонний регіон, економічний розвиток.

\section{Вступ}

Сучасні проблеми економічного розвитку сільських територій України визначаються стрімкими трансформаційними процесами, які відбуваються в глобальній економіці загалом та в межах ЄС зокрема. Одним із пріоритетних напрямів розвитку сільських територій України загалом та іiі прикордонних регіонів зокрема $€$ впровадження маркетингових засобів управління у практику діяльності органів місцевого самоврядування сільських територіальних громад. У прикордонних з ЄС регіонах України впровадження маркетингу сільських територій набуває особливої важливості, насамперед з огляду на сучасні виклики європейської інтеграції. Маркетингові інструменти нарощування потенціалу цих сільських територій спроможні стимулювати зростання їхньої конкурентноспроможності в умовах посилення міграційної кризи, фінансової нестабільності та формування нових безпекових викликів, у тому числі у сфері продовольчої безпеки. Це потребує застосування сучасних управлінських підходів до вирішення актуальних проблем розвитку цих територій.

\section{Матеріал і методи досліджень}

Дослідження проведене на матеріалах наукових публікацій українських і закордонних учених, а також 3 використанням статистичних даних, які є у відкритому доступі.

\section{Результати їх обговорення}

Сфера наукових досліджень, пов'язаних із вивченням та узагальненням основних закономірностей його еволюції, є відносно новою для вітчизняної науки, а розробки, присвячені проблемам розвитку маркетингу сільських територій, висвітлюються у працях українських учених в доволі обмеженому форматі. Переважна частина дослідників концентрує свою увагу на особливостях розвитку регіонального маркетингу, не виокремлюючи проблематики маркетингу сільських територій, у тому числі в контексті стимулювання розвитку та диверсифікації сільської економіки в умовах глобальних та євроінтеграційних змін.

Так, О. Пастернак наголошує на тому, що, зважаючи на недостатню ефективність існуючих підходів регіонального управління, доцільно розвивати маркетинг регіону як ефективно апробований у світовій практиці механізм. При цьому авторка зазначає, що маркетинг регіону дає можливість використовувати маркетинговий тип регіонального менеджменту, який формується для вивчення тих потреб споживачів, які регіон має можливість задовольнити, а не для бажань регіону (Pasternak, 2009).

I. Буднікевич акцентує увагу на проблематиці муніципального маркетингу, зазначаючи: 'Маркетинг стає загальною та центральною концепцією, яка сприяє процесу руху українських міст від моделі бюрократичного міста до іï партнерської форми, зрушенням від ієрархічних відомчих моделей влади до мережних, інформаційних, гнучких" (Budnikevich, 2012).

На думку О. Павлова, для маркетингу першочергового значення набуває економічна сутність іміджу сільських територій, яка проявляється у їхньому позиціонуванні як середовища, сприятливого для занять бізнесом і вкладення капіталу (Pavlov, 2014).

Разом із цим маркетинг сільських територій прикордонних регіонів, як уже зазначалося, має низку характерних ознак, що зумовлюють специфіку його 
розвитку в умовах сучасних викликів європейської інтеграції. Адже нинішній етап європейської інтеграції характеризується низкою тенденцій та економічних явищ планетарного масштабу, пов'язаних з прискоренням інтеграційних процесів і зростанням ролі регіонів у міжнародному поділі праці. При цьому дедалі більшої важливості набуває проблема продовольчого забезпечення населення в різних країнах світу, яка 3 кожним роком відчувається дедалі гостріше. Це актуалізує проблематику просування інтересів прикордонних сільських територій як середовища продукування сільськогосподарських та інших важливих товарів, а також вирішення соціальних проблем мешканців села не лише в регіональному, а й у транскордонному контексті (Hrymak \& Kravtsiv, 2016).

Відповідно до характеру та динаміки особливостей розвитку інституційного середовища, в якому функціонують сільські території прикордонного регіону, відбувається становлення та еволюція основних елементів системи маркетингу кожної з них.

Виходячи з існуючих визначень, система маркетингу охоплює ринкові відносини та інформаційні потоки, які пов'язують суб'єкт маркетингу із ринком. Відповідно вона включає такі елементи, як: загальне уявлення про маркетинг, структура служби маркетингу, людей, які своєю взаємодією забезпечують вироблення маркетингових стратегій, а також тактичних маркетингових рішень, дозволяючи проводити зважену маркетингову товарну і цінову політику.

Водночас окремі дослідники відносять до системи маркетингу низьку взаємопов'язаних складових, які визначають цілі та характер функціонування усіх ланок комплексу маркетингу (маркетингових досліджень, комунікаційну та товарну політику, встановлення цін і просування товарів).

Хай там як - елементи системи маркетингу тісно пов'язані та взаємно переплетені зі складовими мікроі навіть макросередовища кожного суб'єкту управління, що особливо виразно виявляється при здійснені маркетингової діяльності такими складними та багатоплановими соціально-економічними утвореннями, якими є сільські території.

Зважаючи на специфіку розвитку сільських територій прикордонного регіону, формування його системи має низку характерних ознак та особливостей, які дотого ж набувають характерних рис під впливом відповідного інституційного середовища свого функціонування.

Загалом особливості системи маркетингу сільських територій прикордонного регіону можна ідентифікувати у кількох основних площинах: організаційно-економічній (управління, ресурсне забезпечення та інфраструктура), фінансово-інвестиційній (бюджетування, кредитування та інвестування) i соціальнодемографічній (зайнятість і безробіття, якість життя, міграція). При цьому сільські території прикордонних регіонів, які межують з СС, мають низку характерних особливостей щодо розвитку системи маркетингу в кожній $з$ окреслених площин, що вирізняє їх на тлі сільських територій інших прикордонних регіонів держави (табл. 1).

\section{Таблиця 1}

Характерні особливості системи маркетингу сільських територій прикордонного регіону, що межує з ЄС

\begin{tabular}{|c|c|c|c|}
\hline \multirow{2}{*}{$\begin{array}{c}\text { Складові системи } \\
\text { маркетингу }\end{array}$} & \multicolumn{3}{|c|}{ Особливості функціонування у прикордонному з СС регіоні } \\
\hline & Організаційно-економічні & Фінансово-інвестиційні & Соціально-д \\
\hline Сільська територія & $\begin{array}{l}\text { Локалізація поблизу державно- } \\
\text { го кордону створює додаткові } \\
\text { можливості для участі у транс- } \\
\text { кордонному співробітництві, а } \\
\text { відтак і для трансферу техноло- } \\
\text { гій і розвитку інфраструктури }\end{array}$ & $\begin{array}{l}\text { Достатня умотивованість інвес- } \\
\text { торів } 3 \text { країн-членів ЄС вкладати } \\
\text { кошти в реалізацію проектів; } \\
\text { можливість залучати додаткові } \\
\text { кошти за програмами міжнарод- } \\
\text { ної технічної допомоги }\end{array}$ & $\begin{array}{l}\text { Високий рівень трудової } \\
\text { міграції за кордон, що приз- } \\
\text { водить до відтоку кваліфі- } \\
\text { кованих кадрів та погіршен- } \\
\text { ня якості людського і соціа- } \\
\text { льного капіталу села }\end{array}$ \\
\hline Контраг & $\begin{array}{l}\text { Високий рівень впливу євро- } \\
\text { пейської ділової та управлінсь- } \\
\text { кої культури; розгалужена } \\
\text { мережа взаємозв'язків з партне- } \\
\text { рами із країн-членів СС }\end{array}$ & $\begin{array}{l}\text { Наявність додаткових можливо- } \\
\text { стей для залучення фінансово- } \\
\text { кредитних та інвестиційних } \\
\text { ресурсів, спрямованих на реалі- } \\
\text { зацію інноваційних проектів }\end{array}$ & 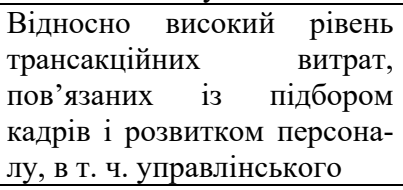 \\
\hline Ринки & $\begin{array}{l}\text { Значний вплив транскордонних } \\
\text { ринків товарів, послуг і робочої } \\
\text { сили }\end{array}$ & $\begin{array}{l}\text { Вищий рівень фінансових ризи- } \\
\text { ків, зумовлених валютними } \\
\text { коливаннями }\end{array}$ & $\begin{array}{l}\text { Наявність ринкових асимет- } \\
\text { рій, пов'язаних із рівнем } \\
\text { життя населення }\end{array}$ \\
\hline Посе & $\begin{array}{l}\text { Відносно розгалужена мережа } \\
\text { посередницьких структур, зок- } \\
\text { рема інститутів громадянського } \\
\text { суспільства }\end{array}$ & $\begin{array}{l}\text { Значний вплив фінансової підт- } \\
\text { римки з боку ЄС, зокрема завдя- } \\
\text { ки програмам міжнародної тех- } \\
\text { нічної допомоги }\end{array}$ & $\begin{array}{l}\text { Висока плинність кадрів та } \\
\text { необхідність забезпечувати } \\
\text { постійний розвиток персо- } \\
\text { налу }\end{array}$ \\
\hline Конкур & $\begin{array}{l}\text { Високий рівень конкуренції } 3 \\
\text { боку сільських територій сусід- } \\
\text { ніх прикордонних регіонів } \\
\text { країн-членів ЄС }\end{array}$ & $\begin{array}{l}\text { Конкуренти володіють вищим } \\
\text { потенціалом залучення інвести- } \\
\text { ційних ресурсів } 3 \text { підприємниць- } \\
\text { ких джерел }\end{array}$ & $\begin{array}{l}\text { Краща якість людських } \\
\text { ресурсів у конкурентів } 3 \\
\text { країн-членів } 6 \text { i нижча } \\
\text { внутрішніх конкурентів } \\
\end{array}$ \\
\hline Контактні аудиторії & $\begin{array}{l}\text { Широкий спектр контактних } \\
\text { аудиторій, які відзначаються } \\
\text { високим рівнем розвиненості та } \\
\text { технологічної оснащеності }\end{array}$ & $\begin{array}{lr}\text { Асиметричність } & \text { фінансово- } \\
\text { iнвестиційного } & \text { забезпечення } \\
\text { контактних аудиторій, локалізо- } \\
\text { ваних по різні боки кордону, та } \\
\text { ïня фінансова неоднорідність }\end{array}$ & $\begin{array}{lr}\text { Значна } & \text { соціально- } \\
\text { демографічна } & \text { сег- } \\
\text { ментованість; високий рівень } \\
\text { латентного впливу на функці- } \\
\text { онування сільської економіки }\end{array}$ \\
\hline
\end{tabular}


Насамперед варто звернути увагу на особливості організаційно-економічного та фінансовоінвестиційного забезпечення самих власне сільських територій, а також на характер соціальнодемографічних процесів, що відбуваються в їх межах. Так, сільські території прикордонних регіонів, локалізованих уздовж кордону між Україною та СС, є активними учасниками транскордонного співробітництва. Воно, зокрема, передбачає реалізацію проектів, спрямованих на розбудову транспортно-логістичної та прикордонної інфраструктури, чим значною мірою сприяє вирішенню організаційно-економічних проблем сільських територій. Разом із цим відбувається поліпшення інвестиційного клімату у вказаних прикордонних регіонах, що посилює увагу до них з боку закордонних інвесторів, у тому числі й у частині вкладення інвестиційних ресурсів у розвиток сільської економіки.

Крім того, розташування сільських територій у межах прикордонних з СС регіонів України створює додаткові фінансові можливості для їхнього розвитку на основі залучення коштів за програмами міжнародної технічної допомоги, які спрямовуються на проекти транскордонного співробітництва у сферах розбудови громадянського суспільства, інформаційних технологій, формування основ економіки знань, підвищення якості людського капіталу, децентралізації влади та проведення адміністративно-територіальної реформи тощо.

Водночас наближеність до кордону тягне за собою i низку негативних аспектів економічного розвитку сільських територій у контексті формування їхньої системи маркетингу. Передусім це стосується значно вищого потенціалу трудової еміграції в сусідні країни-члени $€ С$, ніж це $є$ у віддалених від кордону регіонах України. Причому великий сегмент таких трудових мігрантів перебуває поза межами офіційного сектору економіки.

Ще одним аспектом окресленої проблеми, який виявляється насамперед у контексті довгострокового розвитку системи маркетингу сільських територій, прикордонних з СС регіонів України, є збільшення кількості студентів, які виїжджають на навчання до сусідніх країн, у тому числі з сільської місцевості.

Із цією проблемою пов'язана також інша, а саме асиметричність функціонування транскордонних ринків, які виступають однією із ключових ланок системи маркетингу сільських територій прикордонних регіонів України, насамперед тих, що локалізовані у безпосередній близькості до ЄС. Наприклад, транскордонний аграрний ринок, який охоплює прикордонні території України та Польщі та справляє суттєвий вплив на розвиток маркетингу їх сільських територій як по один, так і по інший бік кордону, значною мірою функціонує в асиметричному режимі. Це зумовлено переважанням одних груп товарів, які експортуються з України до Польщі, та домінуванням зовсім інших товарів у польському експорті до прикордонних регіонів нашої держави.

Асиметричність транскордонних ринків ускладнює розробку якісних маркетингових продуктів, спрямованих на просування інтересів сільських територій прикордонних регіонів України, оскільки фор- мує своєрідні “брендингові стереотипи” в очах потенційних інвесторів і споживачів відповідних товарів та послуг (Borshchevskyiy \& Kulish 2016).

Разом із цим варто зазначити, що окреслені проблеми розвитку системи маркетингу сільських територій у прикордонних регіонах України виявляються різною мірою залежності від типу сільської території. Так, враховуючи типологію сільських територій, варто констатувати, що найбільш підвладними транскордонним ринковим асиметріям виявляються транзитні та власне прикордонні сільські території. Натомість сателітні та неаграрні сільські території прикордонних регіонів України виявляються фактично незалежними від впливу транскордонних ринків, зокрема транскордонного аграрного ринку.

\section{Висновки}

Таким чином, маркетинг сільських територій прикордонних регіонів виконує низку завдань, пов'язаних не лише із просуванням інтересів сільських територіальних громад у траскордонному простоpi та на міжнародному і загальнодержавному рівні.

Особливої важливості виконання цього та інших, пов'язаних із ним завдань, які стоять перед сучасним маркетингом сільських територій прикордонних регіонів набуває в умовах загострення міжнародної конкуренції та посилення нових викликів європейської інтеграції, що постали на нинішньому етапі глобалізації та геополітичної трансформації.

Перспективи подальших досліджень. У руслі окресленої проблематики важливим $\epsilon$ забезпечити підвищення ефективності використання соціальноекономічного потенціалу, а також стимулювати різнобічний розвиток сільської економіки, забезпечуючи підвищення їх конкурентоспроможності в умовах посилення глобальної конкуренції за людські та природні ресурси.

\section{References}

Borshchevskyi, V., Kulish, I., \& Kravtsiv, I. (2016). Marketing of rural areas as a new paradigm of management competitiveness of the region. Socio-economic problems of the modern period of Ukraine, 1(117), 12-15.

Budnikovich, I. (2012). Municipal marketing: theory, methodology, practice. Chernivtsi: Chernivtsi Nat. Univ., 7-15.

Hrymak, O., \& Kravtsiv, I. (2016). The role of marketing in development or rural territories of the near-border region: europian integration contex. Scientific Messenger LNUVMBT named after S.Z. Gzhytsky, 18, 2(69), 33-40. doi: 10.15421/nvlvet6908.

Pasternak, O. (2009). Economic development of the region: marketing support: monograph. NAS of Ukraine. Institute of Regional Studies. Lviv, 10-17.

Pavlov, O. (2014). The image of rural territories as an object of marketing. Economics of the food industry, 4 (24), 42-47.

Tkach, S., \& Urban, I. (2017). Effect of marketing commodity policy agricultural enterprises. Scientific Messenger LNUVMBT named after S.Z. Gzhytsky, 19(76), 108-111. doi: 10.15421/nvlvet7621. 